\title{
Edukasi Pariwisata serta Profesi Bidang Usaha Perjalanan Wisata bagi Siswa SMP Negeri 2 Kelapa Dua Tangerang
}

\author{
Yustisia Kristiana ${ }^{1}$, Reagan Brian ${ }^{2}$, Nova I. B. Sitorus ${ }^{3}$, Stephanie T. Mulyono ${ }^{4}$ \\ ${ }^{1,2,3,4}$ Prodi Usaha Perjalanan Wisata, Fakultas Pariwisata, Universitas Pelita Harapan \\ E-mail: ${ }^{1}$ yustisia.kristiana@uph.edu, ${ }^{2}$ reagan.brian@uph.edu, ${ }^{3}$ nova.sitorus@uph.edu, \\ stephanie.mulyono@uph.edu
}

\begin{abstract}
Abstrak
Pengenalan akan perkembangan pariwisata di tingkat Sekolah Menengah Pertama sangat diperlukan. Hal ini dikarenakan tenaga kerja di industri pariwisata didominasi oleh tamatan pendidikan sampai SMP. Dengan memberikan pengetahuan tentang pariwisata sejak dini diharapkan dapat menghasilkan sumber daya manusia yang memiliki kompetensi dan berdaya saing unggul. Mitra dari kegiatan ini adalah SMP Negeri 2 Kelapa Dua Tangerang. Tujuan dari kegiatan ini adalah untuk meningkatkan pengetahuan siswa tentang pariwisata di Indonesia dan pofesi bidang usaha perjalanan wisata. Metode yang dilakukan melalui beberapa tahapan dimulai dengan survei, koordinasi dengan mitra, persiapan materi, pelaksanaan kegiatan, dan evaluasi kegiatan. Kegiatan ini diikuti oleh peserta sebanyak 50 siswa. Hasil kegiatan ini dapat dinyatakan berhasil. Hal ini dapat dilihat dari (1) tingkat kehadiran peserta (2) tingkat pemahaman peserta, dan (3) perwujudan kerja sama. Implikasi kegiatan ini adalah peningkatan pengetahuan siswa tentang pariwisata dan memahami profesi di bidang usaha perjalanan wisata.
\end{abstract}

Kata kunci: pariwisata, profesi, usaha perjalanan wisata

\begin{abstract}
The introduction of tourism development at the Junior High School level is indispensable. This is because the workforce in the tourism industry is dominated by education graduates up to Junior High School. By providing knowledge about tourism from an early age, it is hoped that it can produce competent and competitive human resources. The partner of this activity is SMP Negeri 2 Kelapa Dua Tangerang. The purpose of this activity is to increase students' knowledge about tourism in Indonesia and profession in travel industry. The method is carried out in several stages starting with surveys, coordination with partners, preparation of materials, implementation, and evaluation. This activity was attended by 50 students. The results of this activity can be declared successful. This can be seen from (1) the level of attendance of the participants (2) the level of understanding of the participants, and (3) the realization of cooperation. The implication of this activity is to increase students' knowledge about tourism and to understand the profession in the travel industry.
\end{abstract}

Keywords: tourism, profession, travel industry

\section{PENDAHULUAN}

Industri pariwisata adalah quick yielding industry dalam mendorong peningkatan devisa negara. Dengan berbagai potensi pariwisata yang luar biasa baik dari sektor alam dan budaya tentunya akan dapat memberi pertumbuhan bagi devisa negara. Menurut data dari Badan Pusat Statistik kunjungan wisatawan mancanegara pada tahun 2019 mencapai 16,11 juta kunjungan atau naik 1,88 persen dibanding jumlah kunjungan selama 2018 yang tercatat 15,81 juta kunjungan [1]. Dalam mendukung pertumbuhan devisa dari sektor pariwisata, maka setiap potensi yang telah ada harus lebih dikembangkan. Berdasarkan Undang-Undang Nomor 10 
tahun 2009 Tentang Kepariwisataan, pariwisata adalah berbagai macam kegiatan wisata dan didukung berbagai fasilitas layanan yang disediakan oleh masyarakat, pengusaha dan pemerintah [2]. Peran serta masyarakat sangat dibutuhkan dalam perkembangan sektor pariwisata. Masyarakat setidaknya harus memiliki tourism minded agar dapat turut serta dalam perkembangan sektor pariwisata.

Menurut data survei angkatan kerja nasional tahun 2019, dilihat dari tingkatan pendidikan yang ditamatkan, tenaga kerja dari tamatan SD atau SMP mencapai 35,29\% [3]. Siswa SMP merupakan siswa yang berada dalam tahapan pencarian identitas diri. Masa usia sekolah menengah masuk dalam kategori masa remaja. Masa remaja dipandang sebagai masa yang menarik perhatian karena kontribusinya yang berdampak pada kehidupan individu dalam masyarakat. Kelompok usia Sekolah Menengah Pertama (SMP) adalah 10-14 tahun [4].

Pariwisata, yang merupakan aktivitas yang tergolong padat karya, membuahkan hasil yang sebagian besar bergantung pada kualitas sumber daya manusia. Untuk mencapai dan mempertahankan kualitas kerja yang optimal dari setiap orang yang bekerja di sektor pariwisata perlu untuk dilakukan program pengembangan [5]. Peran SDM pariwisata yang berhubungan langsung sebagai penyedia layanan memiliki peran penting untuk menyampaikan layanan dan pada akhirnya dapat memberikan kepuasan wisatawan [6]. Dengan memberikan pengetahuan tentang pariwisata sejak dini diharapkan dapat menghasilkan sumber daya manusia yang memiliki kompetensi dan berdaya saing unggul.

Mitra dari kegiatan ini adalah Sekolah Menengah Pertama Negeri (SMPN) 2 Kelapa Dua Tangerang. SMP Negeri 2 Kelapa Dua Tangerang terus berupaya untuk meningkatkan sumber daya manusia, khususnya para siswa untuk mampu menghadapi persaingan global yang terjadi pada saat ini. SMP Negeri 2 Kelapa Dua Tangerang tidak memiliki kegiatan yang berhubungan dengan pariwisata khususnya pengenalan tentang pariwisata dan profesi terkait. Tujuan dari kegiatan ini adalah untuk meningkatkan pengetahuan siswa tentang pariwisata di Indonesia dan pofesi bidang usaha perjalanan wisata.

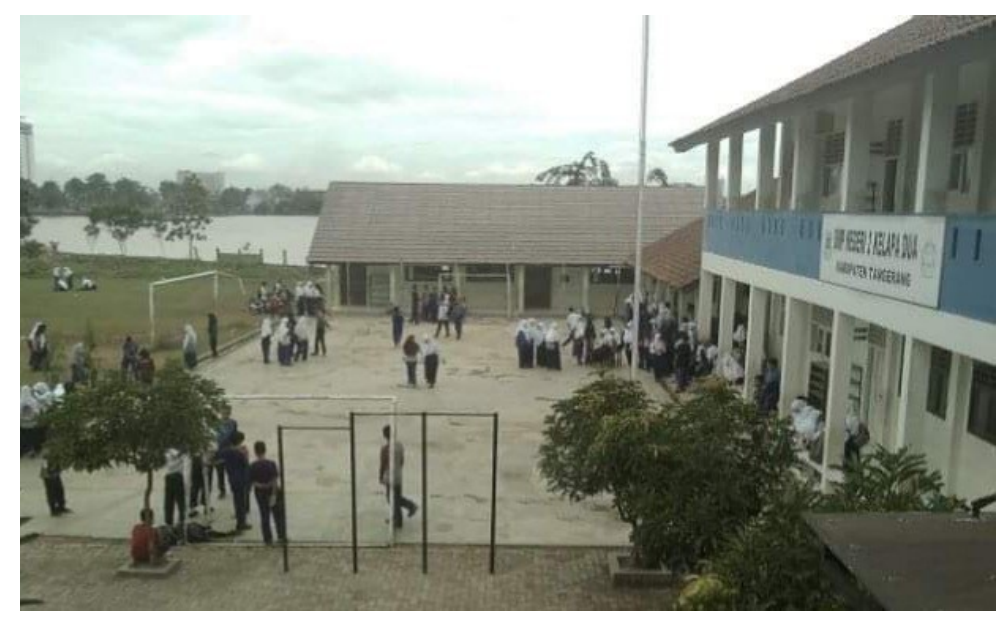

Gambar 1 SMP Negeri 2 Kelapa Dua Tangerang

\section{METODE}

Tahapan dalam melakukan kegiatan bagi siswa SMP Negeri 2 Kelapa Dua Tangerang adalah sebagai berikut: 


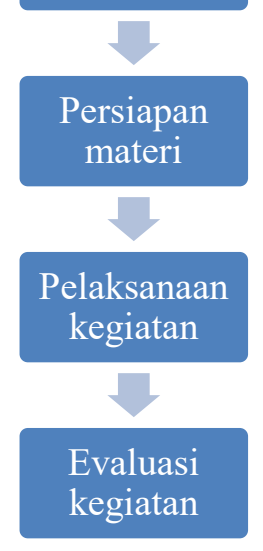

Gambar 2 Tahapan Kegiatan

Tahapan kegiatan dimulai dengan survei. Survei dilakukan untuk mendapatkan gambaran tentang pembelajaran di SMP Negeri 2 Kelapa Dua Tangerang dan kondisi para siswa. Dalam kegiatan survei dapat diketahui kebutuhan siswa tentang pariwisata dan pengenalan profesi yang terkait. Selanjutnya dilakukan koordinasi dengan mitra tentang prosedur perijinan untuk melakukan kegiatan serta berdiskusi mengenai waktu pelaksanaan dan siswa yang dipilih untuk mengikuti kegiatan. Dalam tahapan persiapan kegiatan, tim mempersiapkan materi yang diberikan, berdiskusi tentang peran masing-masing anggota tim, aktivitas yang akan dilakukan untuk mencairkan suasana misalnya dengan permainan, dan penyusunan tes untuk mengevaluasi sejauh mana peserta dapat memahami materi. Pada saat pelaksanaan kegiatan, dipandu oleh tim yang terdiri dari empat orang dosen Fakultas Pariwisata Universitas Pelita Harapan. Satu orang dosen sebagai ketua dan tiga orang lainnya sebagai anggota. Ketua berperan sebagai koordinator kegiatan pelatihan, sedangkan tiga dosen lainnya, sebagai pemateri. Kegiatan diawali dengan pre-test, kemudian masuk pada sesi materi yaitu, sesi pertama materi tentang perkembangan pariwisata di Indonesia, dan materi kedua adalah pengenalan profesi di bidang usaha perjalanan wisata, yaitu tour guide dan tour leader. Tahapan terakhir yaitu evaluasi dengan memberikan post-test kepada peserta kegiatan.

\section{HASIL DAN PEMBAHASAN}

Kegiatan diadakan pada tanggal 7 Maret 2020 dengan peserta adalah siswa SMP Negeri 2 Kelapa Dua Tangerang. Dalam kegiatan ini, peserta yang hadir sebanyak 50 orang siswa dan dihadiri oleh dua guru pendamping. Acara dimulai pada pukul 08.15 diawali dengan pembukaan oleh ketua tim dan penjelasan mengenai tujuan kegiatan. Lalu sebelum diberikan materi, tim memberikan pre-test kepada para peserta untuk memberikan gambaran awal tentang pemahaman peserta tentang pariwisata dan profesi yang terkait.

Selanjutnya adalah sesi materi. Materi diberikan dengan menarik melalui power point serta penjelasan dari pemateri yang dikemas sesuai dengan kebutuhan siswa SMP Negeri 2 Kelapa Dua Tangerang. Presentasi dilakukan dalam dua sesi sesuai dengan topik yang diberikan yaitu perkembangan pariwisata di Indonesia dan profesi di bidang usaha perjalanan wisata. Dalam sesi pertama, peserta diperkenalkan tentang pariwisata dan daya tarik wisata yang ada di Indonesia. Pariwisata terdiri dari empat komponen yaitu atraksi wisata, amenitas, amenitas, dan 
layanan lainnya. Atraksi wisata ditujukan kepada wisatawan, yang merupakan daya tarik dengan tujuan utamanya adalah untuk rekreasi. Atraksi wisata dapat dikelompokkan menjadi atraksi wisata alam, budaya, dan buatan manusia yang dapat menjadi motivasi yang menarik wisatawan. Amenitas adalah fitur tambahan seperti akomodasi, toko, restoran, kafe atau fasilitas lainnya yang dapat menambah daya tarik sebuah destinasi wisata. Aksesibilitas adalah kemudahan akses untuk mencapai destinasi wisata, selain itu ketersediaan transportasi lokal di dalam destinasi wisata. Layanan lainnya adalah layanan penunjang yang disediakan untuk wisatawan seperti terdapatnya Tourist Information Centre [7]. Melalui materi ini, peserta memiliki pengetahuan tentang daya tarik wisata dan contohnya di Indonesia. Selanjutnya dijelaskan juga mengenai 10 destinasi pariwisata prioritas di Indonesia sebagaimana yang dicetuskan oleh Bapak Presiden Joko Widodo. Destinasi pariwisata didefinisikan sebagai wilayah geografis seperti negara, pulau, atau kota [8][9][10]. Definisi lainnya menyatakan bahwa destinasi pariwisata adalah area geografis sebagai lokasi yang dapat menarik wisatawan untuk tinggal secara sementara yang mana lokasi tersebut terdiri dari berbagai produk pariwisata, sehingga membutuhkan berbagai prasyarat untuk mewujudkannya [11].

Sesi kedua adalah tentang profesi di bidang usaha perjalanan wisata. Profesi yang diperkenalkan adalah tour guide dan tour leader. Tour guide memiliki tugas untuk menjelaskan tentang suatu daya tarik wisata di sebuah destinasi pariwisata. Tour guide pada umumnya adalah masyarakat setempat atau orang yang berasal dari lokasi wisata. Sedangkan tour leader bertanggung jawab atas kelompok wisatawan dan harus memiliki pengetahuan tentang destinasi pariwisata yang dikunjungi. Tour leader mengetahui proses perencanaan sebuah perjalanan wisata, dan menguasai rencana perjalanan wisata (itinerary) [12]. Dalam penjelasan profesi di bidang perjalanan wisata juga disampaikan tentang paket wisata. Paket wisata dapat diartikan sebagai suatu perjalanan wisata dengan satu atau beberapa tujuan kunjungan wisata yang disusun dari beberapa fasilitas perjalanan tertentu dalam suatu kegiatan perjalanan wisata, serta ditawarkan dalam satuan harga yang terdiri dari berbagai komponen dari perjalanan wisata [13].

Setelah pemaparan materi selesai, peserta diberikan post-test untuk mengetahui tingkat pemahaman setelah pemberian materi. Kegiatan ini berlangsung dengan lancar dan interaktif, peserta juga banyak terlibat dalam permainan yang dipersiapkan oleh tim.
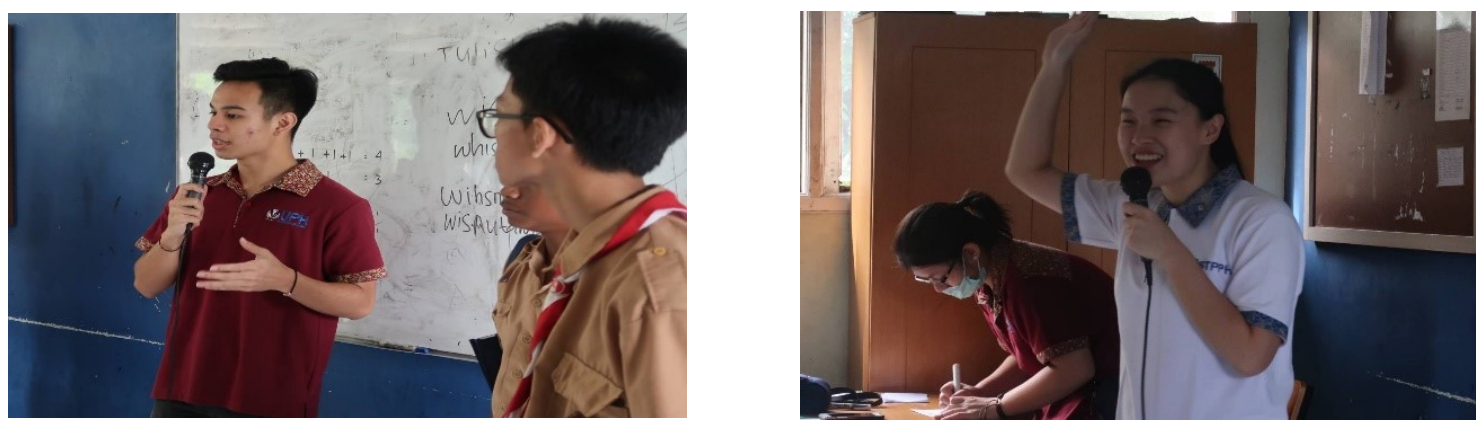

Gambar 3 Saat Kegiatan

Sebelum menutup acara, salah satu guru pendamping menyampaikan kesan-kesan tentang pelaksanaan kegiatan baru kemudian foto bersama. 

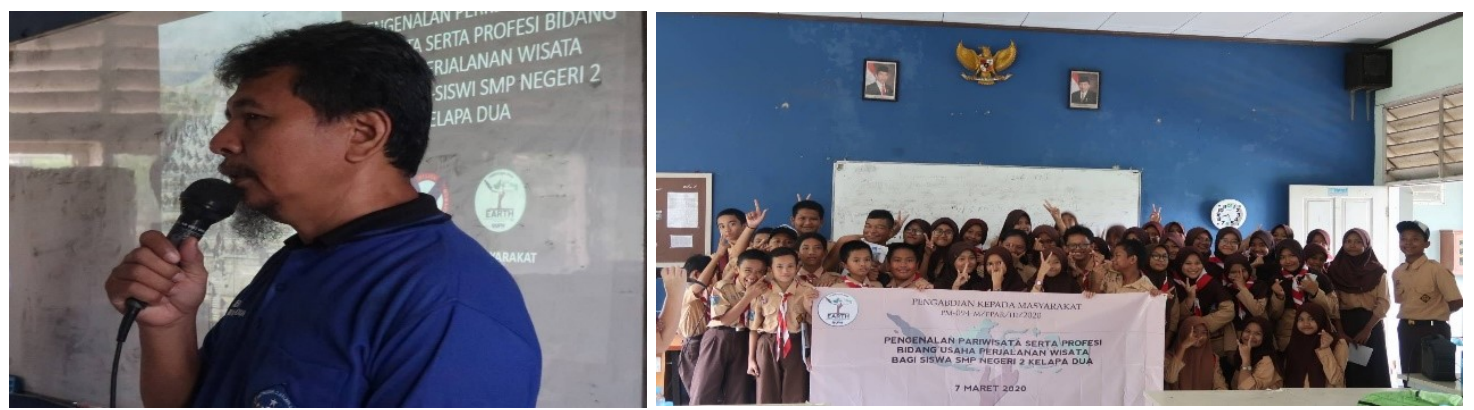

Gambar 4 Penyampaian Kesan dan Foto Bersama

Rincian kegiatan ini dipaparkan sebagai berikut:

Tabel 1 Susunan Acara

\begin{tabular}{|l|l|}
\hline Waktu & \multicolumn{1}{|c|}{ Kegiatan } \\
\hline $07.45-08.15$ & Persiapan untuk memulai PkM dan presentasi \\
\hline $08.15-08.25$ & Sambutan Ketua Tim \\
\hline $08.25-08.55$ & Pre-test \\
\hline $08.55-09.00$ & Persiapan sesi materi \\
\hline $09.00-10.00$ & $\begin{array}{l}\text { Presentasi sesi 1: } \\
\text { Pengenalan Perkembangan Pariwisata di Indonesia }\end{array}$ \\
\hline $10.00-10.15$ & Snack time \\
\hline $10.15-10.30$ & Games \\
\hline $10.30-11.30$ & $\begin{array}{l}\text { Presentasi sesi 2: } \\
\text { Profesi Bidang Usaha Perjalanan Wisata }\end{array}$ \\
\hline $11.30-12.00$ & Post-test \\
\hline $12.00-12.10$ & Pemberian kesan-kesan dari guru pendamping dan pemberian souvenir \\
\hline $12.10-12.30$ & Foto bersama \\
\hline
\end{tabular}

Hasil dari kegiatan edukasi pariwisata serta profesi bidang usaha perjalanan wisata bagi siswa SMP Negeri 2 Kelapa Dua Tangerang dapat dinyatakan berhasil. Hal ini dapat dilihat dari tingkat kehadiran peserta yang mencapai $100 \%$. Tim memperoleh informasi dari mitra bahwa peserta yang akan ikut sebanyak 50 orang, dan pada saat pelaksanaan seluruh peserta hadir dan mengikuti hingga akhir. Selain itu ukuran keberhasilan dilihat dari tingkat pemahaman peserta tentang perkembangan parwisata di Indonesia dan profesi di bidang usaha perjalanan wisata. Hasil rerata pre-test para peserta adalah 50,2 dengan nilai rerata post-test adalah 80,2. Melalui kegiatan ini terjalin kerja sama antara Fakultas Pariwisata Universitas Pelita Harapan dengan SMP Negeri 2 Kelapa Dua dalam upaya pengembangan ilmu pengetahuan.

\section{SIMPULAN DAN SARAN}

Kegiatan edukasi pariwisata serta profesi bidang usaha perjalanan wisata bagi siswa-siswi SMP Negeri 2 Kelapa Dua Tangerang dapat berjalan dengan lancar, dan interaktif. Kegiatan juga dinilai berhasil dengan melihat dari tingkat kehadiran, tingkat pemahaman dan perwujudan kerja sama mitra. Melalui kegiatan ini, terjadi peningkatan pengetahuan siswa tentang pariwisata di Indonesia dan pofesi bidang usaha perjalanan wisata.

Untuk keberlanjutan kegiatan dapat dilakukan penyuluhan lainnya yang terkait dengan pariwisata, dan materi yang disampaikan dibuat dalam bentuk video edukatif dan kreatif sehingga lebih menarik minat peserta di sepanjang acara.

\section{UCAPAN TERIMA KASIH}

Ucapan terima kasih disampaikan kepada Fakultas Pariwisata Universitas Pelita Harapan, Kepala Sekolah SMP Negeri 2 Kelapa Dua Tangerang, guru-guru, dan siswa SMP Negeri SMP Negeri 2 Kelapa Dua Tangerang. 


\section{DAFTAR PUSTAKA}

[1] Badan Pusat Statistik, Statistik Kunjungan Wisatawan Mancanegara Tahun 2019. Jakarta: BPS RI, 2020.

[2] Republik Indonesia, Undang-Undang Republik Indonesia Nomor 10 Tahun 2009 tentang Kepariwisataan. Indonesia, 2009.

[3] Badan Pusat Statistik, Survei Angkatan Kerja Nasional Agustus 2019. Jakarta: BPS RI, 2019.

[4] S. Yusuf, Psikologi Perkembangan Anak \& Remaja. Bandung: Alfabeta, 2004.

[5] S. Herman and P. Zoonosis, "Management of Human Resources in Tourism," Interdiscip. Manag. Res., vol. 11, pp. 180-188, 2015.

[6] A. M. Morrison, Hospitality and Travel Marketing, 4th Ed. Boston, MA: Delmar Cengage Learning, 2010.

[7] C. Cooper, J. Fletcher, A. Fyall, D. Gilbert, and S. Wanhill, Tourism: Principles and Practice. New Jersey: Financial Times/Prentice Hall, 2008.

[8] A. J. Burkart and S. Medlik, Tourism: Past, Present and Future. Oxford: ButterworthHeinemann, 1974.

[9] R. Davidson and R. Maitland, Tourism Destinations. London: Hodder \& Stoughton, 1997.

[10] M. C. Hall, Tourism Planning: Policies, Processes, Relationships. Harlow: Prentice Hall, 2000.

[11] A. Tuohino and H. Konu, "Local stakeholders' views about destination management: Who are leading tourism development?," Tour. Rev. AIEST - Int. Assoc. Sci. Expert. Tour., vol. 69, no. 3, pp. 202-215, 2014.

[12] Y. Kristiana, P. Sinulingga, and R. Lestari, Kunci Sukses Pemandu Wisata. Yogyakarta: Deepublish, 2017.

[13] Nuriata, Paket Wisata: Penyusunan Produk dan Penghitungan Harga. Bandung: Alfabeta, 2014. 